\title{
AN INTERNATIONAL SURVEY OF SHOCK AND VIBRATION TECHNOLOGY
}

\author{
MARCH 1979
}

\author{
Prepared by \\ Henry C. Pusey, Rudolph H. Volin, \\ and J. Gordan Showalter \\ THE SHOCK AND VIBRATION \\ INFORMATION CENTER \\ Naval Research Laboratory, Washington, D.C.
}

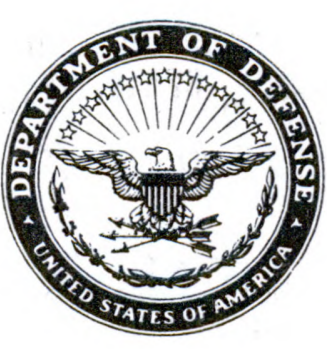

Office of the Undersecretary

of Defense for

Research and Engineering 